\title{
The Effects of Extraction Methods of Mangifera indica and Azadirachta indica Bark on in vitro Antimicrobial Efficacy and Performance of Broiler Chickens
}

\author{
Akeem Ayobami Ayoola $^{1 *}$, Deji. Abiodun Ekunseitan ${ }^{1}$, Sulaiman Babatunde Muhammad $^{2}$, Mutiu Ayogbe Oguntoye ${ }^{3}$ \\ and Yusuf Adewale Adejola ${ }^{4}$ \\ ${ }^{I}$ Department of Animal Production and Health,Federal University ofAgriculture, P.M.B.2240, Abeokuta, Nigeria \\ ${ }^{2}$ Department of Animal Nutrition, Federal University ofAgriculture, P.M.B.2240, Abeokuta, Nigeria \\ ${ }^{3}$ Department of Animal Science, Taraba State University, Jalingo, Nigeria \\ ${ }^{4}$ Department of Animal Production and Technology, Federal College of Agriculture, Ibadan, Nigeria \\ *Corresponding author's Email: ayoolaaa@funaab.edu.ng, ORCID: 0000-0003-1846-8704
}

Received: 18 Dec. 2019

Accepted: 27 Jan. 2020

\begin{abstract}
This study investigated the in vitro efficacy of extracts of Mangifera indica and Azadirachta indica bark obtained by different extraction methods. Also, in an eight-week trial, the effect of these extracts on the performance of broiler chickens were evaluated. The barks were collected, air-dried and pulverized. The samples were extracted using maceration, infusion, and decoction methods. The extracts were screened for their activity against Escherichia coli and Streptococcus aureus. Two hundred and eighty-eight birds were divided into two groups (144 each) administered with $A$. indica or $M$. indica. Each group was subdivided into four subgroups, including control subgroup (no herb) and subgroups administered with bark extracted by one of the three extraction methods. The birds on herbal treatments were not given antibiotics. Results showed that the growth of $E$. coli was more inhibited by the various extracts irrespective of the methods of extraction. Weights were significantly influenced by the interaction between herb types and extraction methods at the starter phase. Infused herbs induced mortality at the finisher phase. In conclusion, S. aureus was more susceptible to the extracts compared to E. coli. However, decocted A. indica and $M$. indica bark, as well as macerated M. indica, showed antimicrobial potency against E. coli. It can be recommended that neem or mango bark extracted by maceration or decoction can be administered orally to broiler chickens especially at the starter phase, for improved performance and reduced mortality.
\end{abstract}

Key words: Antimicrobial assay, Azadirachta indica, Extraction, Mangifera indica, performance

\section{INTRODUCTION}

Poultry farmers are interested in raising their birds to gain market weight as early as possible within the shortest period. This has led to the use of antibiotics that can modify the intestinal microbiota and eliminate harmful bacteria, which in turn improves the growth of the birds. However, there are global concerns over the use of antibiotics for growth promotion or therapy purposes because despite rigorous withdrawal measures to prevent antibiotic residues in food some drugs enter the human food chain and lead to increased antibiotic resistance (Molbak, 2005). For these reasons, European countries have banned the use of antibiotics as growth promoters in animal feed (Castanon, 2007). Therefore, research attention has been shifted to using natural alternatives such as medicinal plants as natural feed additives in poultry diet to enhance production performance as well as to counter bacteria growth (Abaza et al., 2008).
Recent studies have tested the use of herbal extracts as alternatives to antibiotic growth promoters (Biswas et al., 2002; Landy et al., 2011; Sarker et al., 2014). The mechanism of action of bioactive components of these extracts is based on the alteration of the intestinal microbiota, increased enzyme secretion, histomorphological maintenance of the gastrointestinal tract, and enhancement of immune system (Brugalli, 2003). Various research studies have demonstrated antimicrobial, antifungal, anthelmintic and antioxidant effects of plant extracts (Kamel, 2000). Allinson et al. (2013) reported that herbal extracts improve the performance and Feed Conversion Ratio (FCR) in poultry as well as decrease the bacterial and oocyst counts. Neem (Azadirachta indica) is one of the most prominent herbal medicines with different biologically active compounds such as azadirachtin, nimbin, salanin, meliacin, and triterpenoids (National Research Council, 1992; Ansari et al., 2012). 
Mangifera indica (mango) is another plant whose leaves, fruits and barks are known for their medicinal potential and are being explored. Khan et al. (1993) detected compounds such as terpenoidal saponins, polygalacturonase, fructose-1,6- diphosphatase, triterpenoid, 2- hyroxymangiferonic acid tetracyclic triterpenoid and pentacyclic triterpenoid in Mangifera indica extract. The bark infusion has been used as a gargle to treat mouth infections in children (Doughari and Manzara, 2008).

Methods of preparation of crude extracts and their purity greatly influence the inhibitory activity of some herbs against infectious organisms. Also, the extraction method, extraction solvent and the plant part used determines the quality of the extract. Hence, this study aimed to evaluate the performance of broiler chickens administered with neem or mango bark extract prepared by decoction, infusion and maceration techniques.

\section{MATERIALS AND METHODS}

\section{Experimental Site}

The research was carried out at the Poultry Unit of the Directorate of University Farms (DUFARMS), Federal University of Agriculture, Abeokuta, Ogun State, Nigeria.

\section{Ethical approval}

The present study was approved by the ethics and research committee of the College of Animal Science and Livestock Production, Federal University of Agriculture, Abeokuta, Nigeria.

\section{Preparation of plant extracts}

The A. indica and $M$. indica barks were air-dried and pulverized. Three methods of extraction used; maceration, infusion, and decoction. Maceration was performed by soaking of $100 \mathrm{~g}$ of dried barks of each sample in $1 \mathrm{~L}$ of cool water in a covered plastic for 72 hours at room temperature, and then the mixture was strained. The infusion process involved soaking of $100 \mathrm{~g}$ of either $A$. indica or M. indica dried barks in $1 \mathrm{~L}$ of hot water for 12 hours, then was filtered to obtain the extract. Decoction method performed by boiling $100 \mathrm{~g}$ dried barks in $1 \mathrm{~L}$ of water for 1 hour. After cooling, the extract was obtained by decantation.

\section{Assessment of antimicrobial activity of plant extracts \\ The agar well diffusion method was used for the antimicrobial susceptibility test. Mueller Hilton agar was}

prepared according to the manufacturer's specifications. The media were autoclaved and dispensed into sterile Petri-dishes and allowed to gel. Standardized inocula of Escherichia coli and Staphylococcus aureus were streaked on the agar plate. Six wells of $6 \mathrm{~mm}$ each were made in each plate with a central well for positive control using a sterile cork borer. The wells were filled with $0.1 \mathrm{ml}$ of different extracts of two herbs prepared by different methods (infusion, maceration, and decoction). In addition, $0.1 \mathrm{ml}$ of ciprofloxacin were used in separate plates to serve as positive control while sterile distilled water was used as a negative control on separate plates. The plates were allowed to stand for 15 minutes to allow free diffusion of the extracts. After 24 hours of incubation at $37{ }^{\circ} \mathrm{C}$, a transparent plastic meter rule was used to measure the diameters of zone of inhibition, according to Dahiru et al. (2013).

\section{Growth response trial}

A total of 288 day-old broiler chicks was divided into two groups (144 birds each group) administered with A. indica or $M$. indica. Each group was subdivided into four subgroups (36 birds each) including control (no herb administered) and subgroups administered with herbal extracts obtained from different extraction methods: maceration, infusion, and decoction. Hence, the birds were arranged in a $2 \times 4$ experimental layout. Brooding was done for two weeks. Commercial broiler starter was given for the first four weeks, while commercial broiler finisher was given from four weeks to eight weeks (Table 1). The groups were given necessary medications (antibiotics, coccidiostats, and vitamins) and vaccinations (Gumboro vaccine on $7^{\text {th }}$ and $15^{\text {th }}$ day, and Lasota at 4 weeks of age). Birds treated with medicinal herbs were not given antibiotics. Herbs were supplied in drinking water (the extracts were added at a dosage of $150 \mathrm{ml}$ to $1 \mathrm{~L}$ water) for three consecutive days per week for six weeks.

Table 1. Nutrient composition of feed

\begin{tabular}{lcc}
\hline Parameter & $\begin{array}{c}\text { Starter } \\
\text { diet }\end{array}$ & $\begin{array}{c}\text { Finisher } \\
\text { diet }\end{array}$ \\
\hline Crude protein (\%) & 21.00 & 18.00 \\
Fat (\%) & 6.00 & 6.00 \\
Crude fiber (5\%) & 5.00 & 5.00 \\
Calcium (\%) & 1.00 & 1.00 \\
Available phosphorus (\%) & 0.45 & 0.40 \\
Lysine (\%) & 1.00 & 0.85 \\
Methionine (\%) & 0.50 & 0.35 \\
Salt (\%) & 0.30 & 0.30 \\
Metabolizable energy (Kcal/kg) & 2900 & 2800 \\
\hline
\end{tabular}




\section{Data collection}

\section{Feed intake}

The amount of feed given to the birds and the leftover were measured weekly to determine the feed intake according to the following equation:

Feed intake $=$ Feed given - Feed leftover

\section{Body weight and weight gain}

The birds were weighed on a replicate basis at the commencement of the experiment and subsequently every week.

Body weight $(\mathrm{g})=$ Total weight of birds (g) / Total number of birds Total weight gain $(\mathrm{g})=$ Final weight $(\mathrm{g})$ - Initial weight $(\mathrm{g})$

Daily weight gain $=($ Final weight - Initial weight $) /$ Number of days

\section{Feed conversion ratio}

The FCR was calculated as total feed intake divided by weight gain.

$\mathrm{FCR}=$ Total feed intake $(\mathrm{g}) /$ Total weight gain $(\mathrm{g})$

\section{Mortality rate}

The mortality rate was calculated as the total number of dead birds divided by the total number of birds and expressed in percentage.

\section{Statistical analysis}

Data obtained on antibacterial assay were subjected to one-way analysis of variance while those on performance were subjected to one way of analysis of variance in a $2 \times 4$ factorial experimental layout using SPSS software (version 23.0) Significant means were separated using Duncan's multiple range test at $5 \%$ level of significance $(\mathrm{p}<0.05)$.

\section{RESULTS}

Antimicrobial assay of differently extracted Mangifera indica and Azadirachta indica bark on selected bacteria

Figure 1 shows the bar chart representation of the antimicrobial assay of differently extracted $M$. indica and A. indica bark on the Gram-negative organism (Escherichia coli) and gram-positive (Staphylococcus aureus) bacteria. Significant differences $(\mathrm{p}<0.05)$ were observed among the distance of inhibition zone of $E$. coli and $S$. aureus with respect to the type of herbs and extraction methods. The highest zone of inhibition of the two bacteria $(33.00 \mathrm{~mm}$ and $29.00 \mathrm{~mm}$ for E. coli and $S$. aureus, respectively) was recorded for positive control samples (ciprofloxacin) $(\mathrm{p}<0.05)$. However, it was observed that the extracts of $A$. indica obtained by infusion and maceration methods and $M$. indica obtained by infusion did not inhibit the growth of $E$. coli while others had similar values. growth of $S$. aureus was inhibited by the extracts from the various methods of extraction except for extract of $M$. indica obtained by decoction.

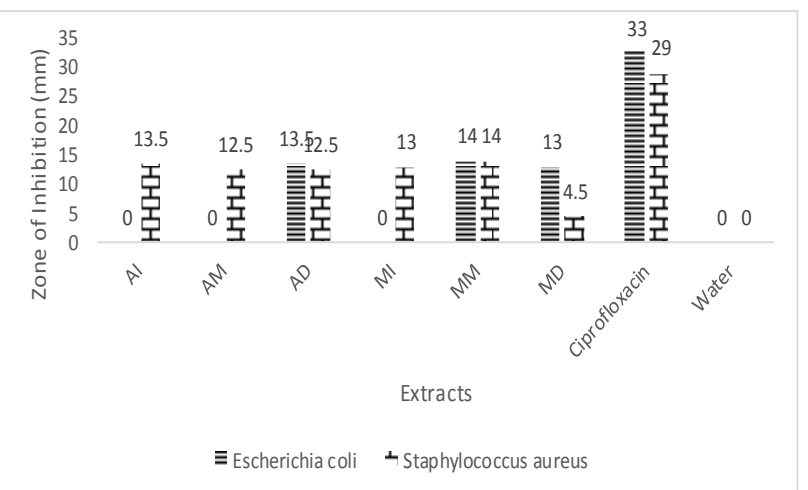

Figure 1. Antimicrobial assay of differently extracted Mangifera indica and Azadirachta indica bark on Escherichia coli and Staphylococcus aureus. AI: Azadirachta indica extracted by infusion; AM: Azadirachta indica extracted by maceration method; AD: Azadirachta indica extracted by decoction; MI: Mangifera indica extracted by infusion; MM: Mangifera indica extracted by maceration method; MD: Mangifera indica extracted by decoction.

Effect of herb types and extraction methods on the performance of broiler chickens at the starter phase

The performance traits of birds were not significantly $(p>0.05)$ affected by herbs and different extraction methods at the starter phase (Table 2). The interaction effect of herbs and extraction methods on the performance of broiler chickens at the starter phase is presented in table 3 . Final weight and total weight gain were highest $(\mathrm{p}<0.05)$ in the control group of birds administered with $M$. indica extract while the lowest were recorded for birds administered with A. indica prepared by the infusion method.

Effect of herbs and extraction methods on the performance of broiler chickens at the finisher phase

The main effect of herbs and extraction methods on the performance of broiler chickens at the finisher phase is presented in table 4. Herb type had no influence ( $p>0.05)$ on all parameters measured. However, the highest $(\mathrm{p}<0.05)$ mortality $(1.67 \%)$ was observed in birds administered herb extract prepared by infusion. The effects of interaction between herbs and extraction methods on the performance of broiler chickens at the finisher phase are shown in table 5. All performance traits evaluated were similar ( $>0.05$ ) except the mortality. Mortality was highest for birds administered with $A$. indica extract prepared by infusion and the lowest was recorded for control birds and birds administered with $M$. indica and A. indica extracts prepared by maceration. 
Table 2. Main effect of different herbs and different extraction methods on the performance of broiler chickens at starter phase

\begin{tabular}{|c|c|c|c|c|c|c|}
\hline \multirow[b]{2}{*}{ Parameters } & \multicolumn{2}{|c|}{ Effect of Herbs } & \multicolumn{4}{|c|}{ Effect of Extraction Methods } \\
\hline & MI & AI & Control & Maceration & Infusion & Decoction \\
\hline Initial weight (g/bird) & $41.01 \pm 0.71$ & $41.14 \pm 2.89$ & $42.06 \pm 3.86$ & $40.89 \pm 0.65$ & $40.71 \pm 0.83$ & $40.64 \pm 1.37$ \\
\hline Final weight (g/bird) & $760.32 \pm 41.12$ & $738.02 \pm 50.67$ & $764.52 \pm 61.13$ & $770.48 \pm 47.96$ & $722.22 \pm 40.02$ & $739.44 \pm 22.62$ \\
\hline $\begin{array}{l}\text { Total Weight gain }(\mathrm{g}) \\
\text { Weight gain/day (g/ bird /day) }\end{array}$ & $\begin{array}{l}719.31 \pm 41.12 \\
25.69 \pm 1.47\end{array}$ & $\begin{array}{l}698.88 \pm 51.90 \\
24.89 \pm 1.85\end{array}$ & $\begin{array}{l}722.46 \pm 63.41 \\
25.80 \pm 2.26\end{array}$ & $\begin{array}{l}729.59 \pm 48.28 \\
26.06 \pm 1.72\end{array}$ & $\begin{array}{l}681.51 \pm 40.29 \\
24.34 \pm 1.44\end{array}$ & $\begin{array}{l}698.81 \pm 22.80 \\
24.96 \pm 0.81\end{array}$ \\
\hline Total feed (g/bird) & $1580.55 \pm 220.69$ & $1603.37 \pm 89.59$ & $1605.78 \pm 55.33$ & $1532.72 \pm 262.85$ & $1538.37 \pm 70.88$ & $1690.97 \pm 169.13$ \\
\hline Total feed/day (g/ bird /day) & $56.45 \pm 7.88$ & $57.26 \pm 3.20$ & $57.35 \pm 1.98$ & $54.74 \pm 9.39$ & $54.94 \pm 2.53$ & $60.39 \pm 6.04$ \\
\hline Total water intake (ml/ bird) & $3588.46 \pm 264.41$ & $3418.44 \pm 146.14$ & $3604.62 \pm 238.75$ & $3555.65 \pm 203.04$ & $3417.06 \pm 167.53$ & $3436.47 \pm 281.60$ \\
\hline Water intake/day (ml/ bird /day) & $128.16 \pm 9.44$ & $122.09 \pm 5.22$ & $128.74 \pm 8.53$ & $126.99 \pm 7.25$ & $122.04 \pm 5.98$ & $122.73 \pm 10.06$ \\
\hline Mortality $(\%)$ & $0.50 \pm 0.80$ & $0.25 \pm 0.62$ & $0.17 \pm 0.41$ & $0.50 \pm 0.84$ & $0.17 \pm 0.41$ & $0.67 \pm 1.03$ \\
\hline FCR & $2.20 \pm 0.33$ & $2.31 \pm 0.22$ & $2.24 \pm 0.26$ & $2.10 \pm 0.38$ & $2.26 \pm 0.16$ & $2.42 \pm 0.27$ \\
\hline
\end{tabular}

Data are expressed as mean \pm standard deviation. MI: Mangifera indica $\quad$ AI: Azadirachta indica $\quad$ FCR: Feed conversion ratio

Table 3. Interaction effects of between herbs and extraction methods on the performance of broiler chickens at starter phase

\begin{tabular}{|c|c|c|c|c|c|c|c|c|}
\hline \multirow[b]{2}{*}{ Parameters } & \multicolumn{4}{|c|}{ Mangifera indica } & \multicolumn{4}{|c|}{ Azadirachta indica } \\
\hline & Control & Maceration & Infusion & Decoction & Control & Maceration & Infusion & Decoction \\
\hline Initial weight (g/bird) & $40.64 \pm 0.84$ & $41.31 \pm 0.63$ & $40.92 \pm 1.02$ & $41.17 \pm 0.44$ & $43.47 \pm 5.12$ & $40.47 \pm 0.38$ & $40.5 \pm 0.73$ & $40.11 \pm 1.91$ \\
\hline Final weight (g/bird) & $801.26 \pm 56.45^{\mathrm{a}}$ & $753.33 \pm 10.14^{\mathrm{ab}}$ & $738.89 \pm 41.94^{\mathrm{ab}}$ & $747.78 \pm 27.15^{\mathrm{ab}}$ & $727.78 \pm 45.90^{\mathrm{ab}}$ & $787.63 \pm 69.03^{\mathrm{ab}}$ & $705.56 \pm 37.58^{\mathrm{b}}$ & $731.11 \pm 18.28^{\mathrm{ab}}$ \\
\hline Total weight gain (g) & $760.62 \pm 55.75^{\mathrm{a}}$ & $712.03 \pm 9.51^{\mathrm{ab}}$ & $697.97 \pm 42.24^{\mathrm{ab}}$ & $706.61 \pm 27.40^{\mathrm{ab}}$ & $684.31 \pm 50.75^{\mathrm{ab}}$ & $747.15 \pm 69.37^{\mathrm{ab}}$ & $665.06 \pm 38.23^{\mathrm{b}}$ & $691.00 \pm 19.13^{\mathrm{ab}}$ \\
\hline Daily weight gain (g/bird) & $27.17 \pm 1.99^{\mathrm{a}}$ & $25.43 \pm 0.34^{\mathrm{ab}}$ & $24.93 \pm 1.51^{\mathrm{ab}}$ & $25.24 \pm 0.98^{\mathrm{ab}}$ & $24.44 \pm 1.82^{\mathrm{ab}}$ & $26.68 \pm 2.48^{\mathrm{ab}}$ & $23.75 \pm 1.37^{\mathrm{b}}$ & $24.68 \pm 0.68^{\mathrm{ab}}$ \\
\hline Total feed intake (g/bird) & $1571.29 \pm 25.26$ & $1438.01 \pm 379.28$ & $1561.47 \pm 90.52$ & $1751.44 \pm 200.56$ & $1640.28 \pm 58.70$ & $1627.42 \pm 44.34$ & $1515.28 \pm 52.61$ & $1630.50 \pm 142.52$ \\
\hline Daily feed intake (g/bird) & $56.12 \pm 0.90$ & $51.36 \pm 13.55$ & $55.77 \pm 3.23$ & $62.55 \pm 7.16$ & $58.58 \pm 2.10$ & $58.12 \pm 1.58$ & $54.12 \pm 1.88$ & $58.23 \pm 5.10$ \\
\hline Total water intake (ml/bird) & $3730.11 \pm 230.67$ & $3710.28 \pm 148.90$ & $3449.48 \pm 192.17$ & $3463.97 \pm 409.44$ & $3479.14 \pm 205.08$ & $3401.01 \pm 95.71$ & $3384.64 \pm 173.44$ & $3408.97 \pm 168.33$ \\
\hline Water intake/day (ml/bird/day) & $133.22 \pm 8.24$ & $132.51 \pm 5.32$ & $123.20 \pm 6.86$ & $123.71 \pm 14.62$ & $124.26 \pm 7.32$ & $121.46 \pm 3.42$ & $120.88 \pm 6.19$ & $121.75 \pm 6.01$ \\
\hline Mortality (\%) & $0.33 \pm 0.58$ & $0.67 \pm 1.15$ & $0.33 \pm 0.58$ & $0.67 \pm 1.15$ & $0 \pm 0$ & $0.33 \pm 0.58$ & $0 \pm 0$ & $0.67 \pm 1.15$ \\
\hline FCR & $2.07 \pm 0.12$ & $2.02 \pm 0.51$ & $2.24 \pm 0.20$ & $2.48 \pm 0.32$ & $2.41 \pm 0.25$ & $2.19 \pm 0.27$ & $2.28 \pm 0.15$ & $2.36 \pm 0.28$ \\
\hline
\end{tabular}

Data are expressed as mean \pm standard deviation. Different superscript letters in the same row indicate significant differences (p<0.05). FCR: Feed conversion ratio 
Table 4. Main effect of herbs and extraction methods on the performance of broiler chickens at finisher phase

\begin{tabular}{|c|c|c|c|c|c|c|}
\hline \multirow[b]{2}{*}{ Parameters } & \multicolumn{2}{|c|}{ Effect of Herbs } & \multicolumn{4}{|c|}{ Effect of Extraction Methods } \\
\hline & MI & AI & Control & Maceration & Infusion & Decoction \\
\hline Initial weight (g/bird) & $760.32 \pm 41.12$ & $738.02 \pm 50.67$ & $764.52 \pm 61.13$ & $770.48 \pm 47.96$ & $722.22 \pm 40.02$ & $739.44 \pm 22.62$ \\
\hline Final weight (g/bird) & $1847.70 \pm 77.95$ & $1825.62 \pm 90.63$ & $1846.09 \pm 121.54$ & $1853.33 \pm 48.32$ & $1836.15 \pm 39.17$ & $1811.07 \pm 110.25$ \\
\hline Total weight gain $(\mathrm{g})$ & $1087.38 \pm 52.34$ & $1087.60 \pm 87.17$ & $1081.57 \pm 83.27$ & $1082.85 \pm 47.62$ & $1113.92 \pm 38.06$ & $1071.63 \pm 104.33$ \\
\hline Daily weight gain (g/bird) & $38.84 \pm 1.87$ & $38.84 \pm 3.11$ & $38.63 \pm 2.98$ & $38.67 \pm 1.70$ & $38.78 \pm 1.36$ & $38.27 \pm 3.73$ \\
\hline Total feed intake (g/bird) & $3349.67 \pm 221.60$ & $3319.51 \pm 172.89$ & $3245.46 \pm 116.22$ & $3334.21 \pm 217.66$ & $3354.95 \pm 121.10$ & $3403.74 \pm 288.70$ \\
\hline Daily feed intake (g/bird) & $119.63 \pm 7.91$ & $118.55 \pm 6.17$ & $115.91 \pm 4.15$ & $119.08 \pm 7.77$ & $119.82 \pm 4.36$ & $121.56 \pm 10.31$ \\
\hline Total water intake (ml/bird) & $9398.34 \pm 744.80$ & $9279.79 \pm 463.35$ & $9424.79 \pm 517.85$ & $9466.10 \pm 775.48$ & $9368.98 \pm 495.06$ & $9096.40 \pm 703.59$ \\
\hline Water intake/day (ml/bird/day) & $335.66 \pm 26.60$ & $331.42 \pm 16.55$ & $336.60 \pm 18.49$ & $338.08 \pm 27.70$ & $334.61 \pm 17.68$ & $324.87 \pm 25.13$ \\
\hline Mortality $(\%)$ & $0.92 \pm 0.67$ & $1.08 \pm 0.79$ & $0.67 \pm 0.52^{\mathrm{b}}$ & $0.67 \pm 0.52^{\mathrm{b}}$ & $1.67 \pm 0.52^{\mathrm{a}}$ & $1.00 \pm 0.89^{\mathrm{ab}}$ \\
\hline FCR & $3.08 \pm 0.22$ & $3.07 \pm 0.24$ & $3.01 \pm 0.17$ & $3.08 \pm 0.07$ & $3.01 \pm 0.12$ & $3.20 \pm 0.40$ \\
\hline
\end{tabular}

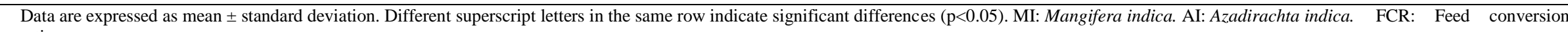
ratio

Table 5. Effects of interaction between herbs and extraction methods on the performance of broiler chickens at finisher phase

\begin{tabular}{|c|c|c|c|c|c|c|c|c|}
\hline \multirow[b]{2}{*}{ Parameters } & \multicolumn{4}{|l|}{ Mangifera indica } & \multicolumn{4}{|c|}{ Azadirachta indica } \\
\hline & Control & Maceration & Infusion & Decoction & Control & Maceration & Infusion & Decoction \\
\hline Initial weight (g/bird) & $801.26 \pm 56.45^{\mathrm{a}}$ & $753.33 \pm 10.14^{\mathrm{ab}}$ & $738.89 \pm 41.94^{\mathrm{ab}}$ & $747.78 \pm 27.15^{\mathrm{ab}}$ & $727.78 \pm 45.90^{\mathrm{ab}}$ & $787.63 \pm 69.03^{\mathrm{ab}}$ & $705.56 \pm 37.58^{b}$ & $731.11 \pm 18.28^{\mathrm{ab}}$ \\
\hline Final weight (g/bird) & $1922.73 \pm 105.92$ & $1855.15 \pm 60.58$ & $1828.96 \pm 6.89$ & $1783.97 \pm 57.77$ & $1769.44 \pm 89.95$ & $1851.52 \pm 46.43$ & $1843.33 \pm 60.28$ & $1838.18 \pm 157.63$ \\
\hline Total weight gain (g) & $1121.47 \pm 52.92$ & $1101.82 \pm 59.19$ & $1090.07 \pm 37.38$ & $1036.19 \pm 37.01$ & $1041.67 \pm 98.79$ & $1063.89 \pm 32.96$ & $1137.78 \pm 22.75$ & $1107.07 \pm 148.56$ \\
\hline Daily weight gain (g/bird) & $40.05 \pm 1.89$ & $39.35 \pm 2.11$ & $38.93 \pm 1.33$ & $37.01 \pm 1.32$ & $37.20 \pm 3.53$ & $37.10 \pm 1.18$ & $40.63 \pm 0.81$ & $39.54 \pm 5.31$ \\
\hline Total feed intake (g/bird) & $3277.53 \pm 96.02$ & $3402.51 \pm 283.09$ & $3332.37 \pm 148.16$ & $3386.27 \pm 379.88$ & $3213.38 \pm 146.49$ & $3265.91 \pm 155.90$ & $3377.53 \pm 117.16$ & $3421.21 \pm 251.30$ \\
\hline Daily feed intake (g/bird) & $117.05 \pm 3.43$ & $121.52 \pm 10.11$ & $119.01 \pm 5.29$ & $120.94 \pm 13.57$ & $114.76 \pm 5.23$ & $116.64 \pm 5.57$ & $120.63 \pm 4.18$ & $122.19 \pm 8.97$ \\
\hline Total water intake (ml/bird) & $9853.93 \pm 328.54$ & $9792.97 \pm 1067.47$ & $9130.47 \pm 408.60$ & $8816.00 \pm 689.49$ & $8995.66 \pm 100.11$ & $9139.24 \pm 208.38$ & $9607.49 \pm 524.51$ & $9376.79 \pm 725.49$ \\
\hline Water intake/day $(\mathrm{ml} /$ bird/day $)$ & $351.93 \pm 11.73$ & $349.75 \pm 38.12$ & $326.09 \pm 14.59$ & $314.86 \pm 24.62$ & $321.27 \pm 3.58$ & $326.40 \pm 7.44$ & $343.12 \pm 18.73$ & $334.89 \pm 25.91$ \\
\hline Mortality $(\%)$ & $0.67 \pm 0.58^{\mathrm{b}}$ & $0.67 \pm 0.58^{\mathrm{b}}$ & $1.33 \pm 0.58^{\mathrm{ab}}$ & $1.00 \pm 1.00^{\mathrm{ab}}$ & $0.67 \pm 0.58^{\mathrm{b}}$ & $0.67 \pm 0.58^{\mathrm{b}}$ & $2.00 \pm 0^{\mathrm{a}}$ & $1.00 \pm 1.00^{\mathrm{ab}}$ \\
\hline FCR & $2.92 \pm 0.10$ & $3.08 \pm 0.09$ & $3.06 \pm 0.09$ & $3.27 \pm 0.37$ & $3.10 \pm 0.20$ & $3.07 \pm 0.05$ & $2.97 \pm 0.14$ & $3.13 \pm 0.49$ \\
\hline
\end{tabular}

Data are expressed as mean \pm standard deviation. Different superscript letters in the same row indicate significant differences ( $\mathrm{p}<0.05)$. FCR: Feed conversion ratio 


\section{DISCUSSIONS}

Failure of bark extracts of infused A. indica, infused $M$. indica and macerated $A$. indica to inhibit $E$. coli growth (no inhibition zone diameter observed) indicates the resistance of the organism to those extracts. The appearance of the zone of inhibition by herbs prepared by decoction may indicate that this method can lead to a better release of phytochemicals and active ingredients effective in inhibiting $E$. coli activity. Since infusion and maceration techniques involve soaking in hot and cold water, respectively, thus the antimicrobial efficacy could be less potent due to reduced quality and quantity of phyto-components released, resulting in the bacteria resistant. Azwanida (2015) stated that decoction is the most effective method for extracting hard plant materials and heat-stable compounds.

It has been documented that E. coli can rapidly change their genetic makeup as gram-negative bacteria, this enables them to develop resistance to antibiotics (Uwimbabazi et al. 2015). This can be attributed to the lower potency of the extracts on E. coli compared to $S$. aureus. Resistant bacteria change their cell walls lightly, so the antibiotics cannot attach, or they produce enzymes to disable the antibiotics. Hence, the result of this study is inconsistent with findings of Gajendrasinh et al. (2012) who reported that aqueous and ethanol extracts of $A$. indica leaves were most effective against $E$. coli. The variation observed in the result could be attributed to the differences in solvent types and plant parts used.

$M$. indica showed a slightly stronger potency on both bacteria when extracted by the maceration method compared to infused and macerated A. indica and infused $M$. indica This finding indicated the role of different methods of extraction in influencing the potency of the extract.

The similar performance in birds administered with A. indica and $M$. indica at the starter and finisher phase is an indication that both herbs induced similar growth response in the birds. Meanwhile, in a similar study by Sarker et al. (2014), it was reported that body weight and weekly weight gain in broilers were improved with oral supplementation of $1 \%$ aqueous neem leaf extract compared to control group.

The fairly poor performance recorded for birds administered with infused $A$. indica bark indicates that growth performance decreased at the starter phase. This finding may indicate that the birds cannot well tolerate infused extract or that the potency of the herb prepared through this method is lower compared to other methods.
Infusion is generally used for softer parts including leaves and flowers, thus this method may not effectively release the beneficial bioactive components in plant parts such as bark that was used in this study. Also, the temperature might not be adequate to destroy or reduce the quantity of antinutritional components of the extract which could impair feed utilization and hence suppress the growth. Tannin is a known antinutritional factor present in both herbs used and can be degraded at high temperatures. However, the temperature at infusion might not be sufficient to degrade it. Tannins in diet decrease palatability, reduce feed intake, suppress growth rate, impair net metabolizable energy and protein digestibility resulting in poor feed efficiency in animals. Tannins can also inhibit cellular protein synthesis by forming irreversible complexes with proline-rich proteins (Adejuwon et al., 2011). Contrarily, similar feed intake and FCR in the birds administered with infused bark extract with other groups in this study could be due to the fact that the herbs were administered orally and not incorporated into the diet.

The insignificant effect of the interaction of herbs and extraction methods on all performance parameters with the exception of mortality at the finisher phase corroborates the statement reported by Ayoola et al. (2015) that neem leaf had no significant effect on broiler performance at the finisher phase. Some authors found no effect of these additives on growth, feed consumption or FCR in broilers (Cross et al., 2007; Ocak, et al., 2008).

The similar effect of water intake throughout the study is in agreement with Durrani et al. (2007), who reported the non-significant effect of medicinal herbs on water intake of birds.

The highest mortality recorded in birds administered with the extract obtained by the infusion method at the finisher phase could be attributed to the accumulation of tannin which eventually became toxic and induce mortality among the birds. Also, temperature in the infusion method may not be enough to destroy toxic components present, unlike decoction which involves higher temperature and longer heating time. Thermal treatment of plant materials reduces the tannin content. (Rakic, 2004). Levels of tannin above 5\% are often lethal, and it was reported that neem bark contains about $14 \%$ tannin (NRC, 1992). It is thought that the mortality rate was higher due to inability of the infusion method to properly reduce the tannin content. It can be also related to the length of time because too long infusion can cause high tannin content and tannins at high levels can result in mortality. According to Calislar (2017), poultry develops 
bone problems and necrotic organs (crop, gizzard, and duodenum) resulting from liver and kidney poisoning due to excess tannin consumption. Smulikowska et al. (2001) also reported that inclusion of feed ingredients containing tannins resulted in undesirable physiological and biochemical effects including growth inhibition and negative nitrogen balances.

\section{CONCLUSIONS}

This study concludes that gram-positive (Staphylococcus aureus) bacteria in comparison to gram-negative (Escherichia coli) bacteria are more susceptible to antimicrobial effect of extracts of Mangifera indica and Azadirachta indica, regardless of the extraction methods. Mangifera indica and Azadirachta indica extracts had similar effects on the growth performance of broiler chickens at starter and finisher phases. Administration of infused neem bark decreased weight gain at the starter phase and increased mortality at the finisher phase. Hence, it can be recommended that neem or mango bark extracted by maceration or decoction can be administered orally to broiler chickens especially at the starter phase to improve performance and reduce mortality.

\section{DECLARATIONS}

\section{Acknowledgment}

The authors would like to acknowledge the efforts of Mr. Rahman, the laboratory technologist in the Department of Veterinary Medicine, for his assistance in carrying out the in vitro aspect of this study. The authors equally appreciate senior colleagues for their financial contribution and encouragement.

\section{Competing interest}

The authors have declared that no competing interest exists.

\section{Authors' contribution}

Ayoola A. A. conceptualized and designed the experiment, collected data and wrote the manuscript draft. Ekunseitan D. A. analyzed the data and interpreted the results. Muhammad S. B. and Oguntoye M. A. read and revised the first and second drafts and Adejola Y. A. assisted in manuscript writing.

\section{REFERENCES}

Abaza IM, Sheheta MA, Shoeb MS and Hassan II (2008). Evaluation of some natural feed additives in growing chicks' diet. International
Journal of Poultry Science, 7:872-879. DOI: https://doi.org/10.3923/ijps.2008.872.879

Adejuwon AO, Agbaje EO and Idika N (2011). Antifungal and antibacterial activities of aqueous and methanolic root extracts of Carica papaya Linn. (Caricaceae). International Research Journal of Microbiology, 2(8): 270-277. Available at: https://www.interesjournals.org/archive/irjm-volume-2-issue-8year-2011.html

Allinson IB, Ekunseitan DA, Ayoola AA, Ogunade IM and Njoku CP (2013). Effect of herbal supplement on growth response and faecal egg counts of cockerels. Online Journal of Animal Feed Resource, 3: 68-73. DOI: https://doi.org/10.3923/pjbs.2013.1022.1027

Ansari SH, Islam F and Sameem M (2012). Influence of nanotechnology on herbal drugs: A review. Journal Advance Pharmaceutical Technology Research, 3: 142-146. DOI: https://doi.org/10.4103/2231-4040.101006

Ayoola AA, Egbeyale LT, Ekunseitan DA, Adegoke AV and Adeyeri OP (2015). The effect of neem (Azadirachta indica) leaf meal on growth performance and carcass characteristics of broiler chickens. Nigerian Journal of Animal Production, 42(2): 141-150. Available at: https://www.ajol.info/index.php/njap/issue/view/13764

Biswas K, Chattopadhyay I, Banerjee RK and Bandyopadhyay U (2002). Biological activities and medicinal properties of Neem (Azadirachta indica). Current Science, 82, 1336-1345. Available at: http://medicalmate.gr/img/cms/Vivliothiki\%20Gia\%20Epaggelmati es\%20Ygeias/wound\%20management/Allegato\%20NE\%2002.pdf

Brugalli I (2003). Alternative feeding: The use of herbal medicines and nutraceuticals as moduladoresda immunity and animal performance. Proceedings of Symposium on Management and Nutricao Poultry and Swine. Campinas, Sao Paulo. Brazil. Campinas: CBNA. pp. 167-182.

Calislar S (2017). Tannins and their effect on poultry nutrition. Proceeding of International Conference on Agriculture, Forest, Food Sciences and Technologies (ICAFOF 2017 Cappadocia / Turkey). Available at: https://www.researchgate.net/ publication/317168301_Tannins_and_Their_Effects_on_Poultry_N utrition

Castanon JIR (2007). History of the use of antibiotic as growth promoters in European poultry feeds. Poultry Science, 86: 2466-2471. DOI: https://doi.org/10.3382/ps.2007-00249

Cross DE, McDevitt RM, Hillman K. and Acamovic T (2007). The effect of herbs and their associated essential oils on performance, dietary digestibility and gut microflora in chickens from 7 to 28 days of age. British Poultry Science, 48: 496-506. DOI: https://doi.org/10.1080/00071660701463221

Dahiru D, Malgwi AR and Sambo SH (2013). Growth inhibitory effect of Sennasiamea leaves extracts on selected microorganism. American Journal of Medicine and Medical Sciences, 3(5): 334- 337.

Doughari JH and Manzara S (2008). In vitro antibacterial activity of crude leaf extracts of Mangifera indica Linn. African Journal of Microbiology Research, 2: 067-072. Available at: https://academicjournals.org/journal/AJMR/archive/2008

Durrani FR, Sultan A, Ahmed S, Chand N, Khattak, FM, and Durrani Z (2007). Efficacy of Aniseed Extract as immune Stimulant and Growth Promoter in Broiler Chicks. Pakistan Journal of Biological Sciences, $\quad 10$ : 3718-3721. DOI: https://doi.org/10.3923/pjbs.2007.3718.3721

Gajendrasinh PR, Bhavika MK, Rohit, S, Hetal, A and Prajapati PK (2012). In vitro antibacterial study of two commonly used medicinal plants in Ayurveda: Neem (Azadirachta indica L.) and Tulsi (Ocimum sanctum L.). International Journal of Pharmaceutical and Biological Archives, 3(3): 582-586. Available at: http://www.ijpba.info/ijpba/index.php/ijpba/article/view/677

Kamel C (2000). A novel look at a classic approach of plant extracts. Feed Mix- The International Journal on Feed, Nutrition and Technology, 9(6): 19-24. Available at: https://www.worldcat.org 
Landy N, Ghalamkari GH and Toghyani M (2011). Performance, carcass characteristics, and immunity in broiler chickens fed dietary Neem (Azadirachta indica) as alternative for an antibiotic growth promoter. Livestock Science, 142: 305-309. DOI: https://doi.org/10.1016/j.livsci.2011.08.017

Molbak K (2005). Human health consequences of antimicrobial drugresistant Salmonella and other foodborne pathogens. Food Safety, 41: 1613-1620. DOI:http//doi.org/10.1086/497599

National Research Council (NRC) (1992). Neem: A tree for solving global problems. National Academy Press, Washington, DC. United State of America., pp: 141-142. Accessed in November 2017. DOI: https://doi.org/10.17226/1924

Ocak N, Erner G, Burak AK, Sungu M, Altop A and Ozmen A (2008). Performance of broilers fed diets supplemented with dried peppermint (Mentha piperita L.) or thyme (Thymus vulgaris L) leaves as growth promoter source. Czech Journal of Animal Science, 53(4): 169-175. DOI: https://doi.org/10.17221/373-cjas

Rakić S, Maletić R, Perunović M and Svrzić G (2004). Influence of thermal treatment on tannin content and antioxidation effect of oak acorn Quercus cerris extract. Journal of Agricultural Sciences, 49 (1):97- 107. DOI: https://doi.org/10.2298/jas0401097r
Sarker SK, Mostofa M, Akter F, Rahman MM and Sultana MR (2014). Effects of aqueous extract of neem (Azadirachta indica) leaves as growth promoter and anti-colibacillosis in broilers. Bangladesh Journal of Animal Science, 43(2): 138-141. DOI: https://doi.org/10.3329/bjas.v43i2.20715

Savage GP (2003). Chemical and Physical properties of saponins. Encyclopedia of Food Sciences and Nutrition. (Second edition). Academic Press, London, pp: 5095- 5096. DOI: https://doi.org/10.1016/b0-12-227055-x/01050-6

Smulikowska $\quad$ S, Pastuszewska $\quad$ B, Swiech E, Ochtabinska A, Mieczkowska A, Nguyen VC and Buraczewska L (2001). Tannin content affects negatively nutritive value of pea for monogastrics. Journal of Animal and Feed Sciences, 10:511523. Available at: https://pdfs.semanticscholar.org/0bbd/e036b365d03981b02dcc1013 155590fe4858.pdf

Uwimbabazi F, Uwimana $\mathrm{J}$ and Rutanga $\mathrm{J}$ (2015). Assessment of antibacterial activity of Neem plant (Azadirachta indica) on Staphylococcus aureus and Escherichia coli. Journal of Medicinal Plants Studies, 3(4): 85-91 Available at: http://www.plantsjournal.com/archives/?year=2015\&vol=3\&issue= $\underline{4 \& \text { part }=\mathrm{B}}$ 